
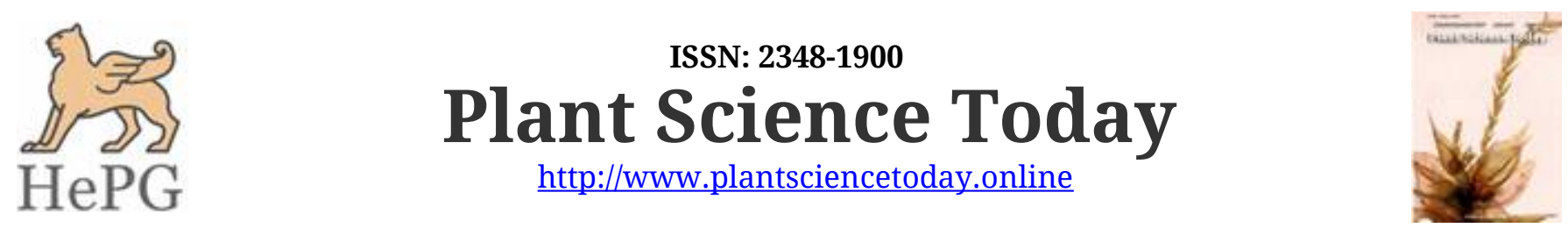

OPEN 6 ACcess

Mini Review

\title{
Review on medicinal importance of Vigna genus
}

\author{
Sonali Pandey \\ Department of Bioscience and Biotechnology, Banasthali Vidyapith, Rajasthan 304 022, India
}

\section{Article history}

Received: 15 July 2019

Accepted: 05 September 2019

Published: 01 October 2019

\section{Publisher}

Horizon e-Publishing Group

\section{*Correspondence}

Sonali Pandey

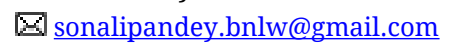

\begin{abstract}
Globally, there are more than 500,000 plant species (green scum, duckweed, lichens, liverworts, fungi, ferns, conifers, mosses and flowering plants etc.) that maintain earth's environmental equilibrium, ecosystem stability and also possess vast endemic, aesthetic and cultural importance, provide medicine, food, fuel, shelter and clothing. Plants are used as therapeutic agents to improve health by a large part of population. Several clinical facts suggest that plant derived foods hold various potential health benefits and well known as neutraceuticals. These are the products that are used as food or as a part of food (foodstuffs), able to cure and prevent diseases in addition to their basic nutritional value. More than 200,000 chemical compounds are synthesized by plants and no doubt, also possess medicinal importance. Worldwide, about $70 \%$ plant based preparations are used as traditional medicines and also facilitate the base for 50 percent of prescription and/or over the counter drugs used in the Western-type practice of medicine. For underdeveloped and developing countries, it is a need to provide safe, efficient and cheap medications. In various part of India medicinal plants are widely distributed and always have increasing demand due to their medicinal properties. The present review is focused on the genus Vigna which is widely cultivated and used as neutraceuticals. They grow in varied climatic zones, in high temperatures, low rainfall and poor soils with low input in form of fertiliser and irrigation that make them valuable crop plants. As Vigna is an important genus that fulfils the food demand, useful in cosmetics and medicines, there is scope to enhance its productivity via resource conservation, optimum use of rainwater, bridging the yield gaps and innovations in technology transfer and up scaling. One of the important steps to find out a way to increase the production is the detection and analysis of naturally occurring DNA sequence variation by using DNA markers or molecular markers as these markers are indispensable tool that construct maps of genetic linkage and mark the agronomically important traits.
\end{abstract}

Keywords: Neutraceuticals; Pharmacognosy; Phytochemicals; Environmental stress

Citation: Pandey S. Review on medicinal importance of Vigna genus. Plant Science Today 2019;6(4):450-456. https://doi.org/10.14719/pst.2019.6.4.614

Copyright: (c) Pandey (2019). This is an open-access article distributed under the terms of the Creative Commons Attribution License, which permits unrestricted use, distribution, and reproduction in any medium, provided the original author and source are credited (https://creativecommons.org/licenses/by/4.0/).

Indexing: Plant Science Today is covered by Scopus, Web of Science, BIOSIS Previews, ESCI, CAS, AGRIS, CABI, Google Scholar, etc. Full list at http://www.plantsciencetoday.online

\section{Introduction}

The name of the Vigna genus is derived from an Italian botanist of the 17 th century Dominico Vigna. It comprises around 150 species (1). It is closely related to Phaseolus. Most commonly cultivated crops of the Vigna genus are blackgram (Vigna mungo), cowpea (Vigna unguiculata), greengram (Vigna radiata), bambara groundnut (Vigna subterranea), azuki bean (Vigna angularis), snail 
Table 1. Different Vigna species and their medicinal importance

\begin{tabular}{|c|c|c|c|}
\hline $\begin{array}{l}\text { S. } \\
\text { No. }\end{array}$ & $\begin{array}{l}\text { Vigna } \\
\text { species }\end{array}$ & Medicinal value & References \\
\hline 1. & V. marina & $\begin{array}{l}\text { Fractured bone, food poisoning, weakness after child birth, headache, stomach-ache, } \\
\text { asthma, poultice, mouth infections and abscesses. }\end{array}$ & $(7,59)$ \\
\hline 2. & V. radiata & $\begin{array}{l}\text { Light diet, fever, dysentery, cooling and astringent, vertigo, beri-beri, polyneuritis } \\
\text { granuloma, poultice (treatment of scabies, psoriasis and other skin ailments), heat stroke, } \\
\text { antidiahrroeal, antioxidant, antimicrobial, anti-inflammatory, antitumor, antidiabetic, } \\
\text { antihypertensive, gastritis, uraemia, hypercholesterolemia, coronary heart disease, lipid } \\
\text { metabolism accommodation, hepatitis, toxicosis, cholera, corneal opacity and macula. }\end{array}$ & $\begin{array}{l}(7,17-20,26, \\
60-67)\end{array}$ \\
\hline 3. & $\begin{array}{l}V . \\
\text { unguiculata }\end{array}$ & $\begin{array}{l}\text { Neuritis, insomnia, weakness of memory, indigestion, dyspepsia, sensation of pins and } \\
\text { needles in limbs, periodic palpitation, congestive cardiac failure, stomatitis, corneal ulcers, } \\
\text { coleic diseases, kwasiorkar, marasmus, hyperacidity, nausea and vomiting, malnutrition } \\
\text { and micronutrient deficiencies. }\end{array}$ & $(7,34,68)$ \\
\hline 4. & V. vexillata & Parkinson's disease. & (7) \\
\hline 5. & V. mungo & $\begin{array}{l}\text { Liver disorders, rheumatism, infection of nervous system, aching bones, dropsy, cephalgia, } \\
\text { anti-hypertensive and antidiabetic, hypolidimic action. }\end{array}$ & $(7,66,69-72)$ \\
\hline 6. & V. philosa & $\begin{array}{l}\text { Roots are used as aphrodisiac and germicidal, cough, fever, diarrhoea, hemoroids, } \\
\text { opthalomapathy, burning sensation, dyspepsia. }\end{array}$ & (7) \\
\hline
\end{tabular}

Table 2. Phytochemicals reported from Vigna sp.

$\begin{array}{cccc}\text { S. } & \text { Vigna } & \text { Phytochemicals Reported } & \text { References } \\ \text { No. } & \text { species } & & \end{array}$

1. V. mungo Glycosides, tannins, alkaloids, flavonoids, saponins, terpenoids, quinone, sterols, ethylbenzene, pentane, 1,1-diethoxy-, hexanoic acid, propane, 1,1,3-triethoxy-, octanoic acid, decanoic acid, dodecanoic acid, 3-hydroxy-, (1,1'-bicyclopropyl)-2-octanoic acid, 2'hexyl-, methyl ester, desulphosinigrin, 3-O-methyl-d-glucose, phthalic acid, butyl isohexyl ester, ethanol, 2-(9-octadecenyloxy)-,(Z)-, n-hexadecanoic acid, hexadecanoic acid, 9,12octadecadienoyl chloride, (Z,Z)-, oleic Acid, octadecanoic acid, ethyl ester, genistein, 2'hydroxy-genistein, 2'-hydroxydaidzein, kievitone, cyclokievitone

\begin{tabular}{lll}
\hline 2. & V. angularis & Vitexin, isovitexin \\
\hline 3. & V. radiata & Steroids, triterpenoids, glycosides, flavonoids, alkaloids, polyphenols, tannins, saponins, \\
& & daidzin, daizein, ononin, formononetin, isoformononetin, 6,7,4'-trihydroxyisoflavone, \\
& 6,7,4'-trihydroxyisoflavone, genistin, sissotrin, genistein, prunetin, biochanin A, 6"--0- \\
& acetylgenistin, 5,7,4'-trimethoxyisoflavone, 2'-hydroxygenistein, apigenin, vitexin, \\
& isovitexin, rutin, quercetin-3-glucoside, quercetin, kaempferol, myricetin, rhamnetin, \\
& kaempferitrin, kaempferol-3-rutinoside, 3,5,7,3',4'-pentahydroxyflavonol, 3,7,8,3',4' - \\
& pentahydroxyflavonol, naringenin-7-glucoside, naringin, neohesperidin, hesperetin, 5,7- \\
& dihydroxyflavanone, eriodictyol-7-glucoside, eriodictyol, naringenin, rhododendrin, \\
& scopoletin, pomiferin, delphinidin, 2',4,4'-trihydroxychalcone, phloretin, coumestrol, osajin, \\
& p-hydroxybenzoic, protocatechuic, syringic, gallic acid, vanillic acid, gentisic acid, shikimic \\
& acid, p-coumaric, cinnamic acid, caffeic acid, ferulic, chlorogenic acid.
\end{tabular}

4. V. Delphinidin 3-O-â-glucoside, petunidin 3-O-â-glucoside, and malvidin 3-O-â-glucoside, subterranea alkaloids, saponin, flavonoids, carbohydrate, fats, oil, resins, terpenoids, steroids, glycosides, proteins.

(73-76) Amino acids, carbohydrates, glycosides, flavonoids, tannins, phenolic compounds,

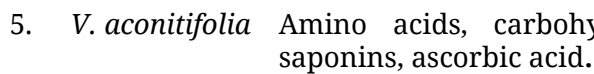

\begin{tabular}{llll} 
6. & $\begin{array}{l}\text { V. } \\
\text { unguiculata }\end{array}$ & $\begin{array}{l}\text { Alkaloids, saponin, flavonoids, tannins, glycosides, sterols, carbohydrates, polyphenols, (80, 81, 83-85) } \\
\text { reducing sugar, fats, oil, proteins. }\end{array}$ \\
\hline 7. & V. umbellata & $\begin{array}{l}\text { p-coumaric acid, ferulic acid, sinapic acid, catechin, epicatechin, vitexin isovitexin } \\
\text { quercetin. }\end{array}$ & (86) \\
\hline 8. & V. vexillata & Sterol, isoflavone. & (87) \\
\hline
\end{tabular}

bean (Vigna caracalla), pencil yam (Vigna lanceolata), Vigna marina, Vigna parkeri, wondering cowpea (Vigna speciosa), jungle mat bean (Vigna trilobata), red bean (Vigna umbellatA), moth bean (Vigna aconitifolia) and zombie pea (Vigna vexillata) etc. Cowpea, mungbean, blackgram and azuki bean are called as orphan grain legumes since there is little study has been done on these crops and limited genetic and genomic resources are available (2-3). Some wild species of Vigna are well known for various uses such as soil enrichment material, human food, medicinal plants, soil erosion-preventing materials and animal feed (4). Legumes such as bambara groundnuts ( $V$. subterranea), black gram ( $V$. mungo), peas (Pisum sativum), green gram ( $V$. radiata) and beans (Phaseolus vulgaris) etc. occupy around $20-57 \%$ of cultivable land in different countries due to their properties (5). It is well known that there are various environmental stresses i.e. biotic and abiotic that adversely affect the crop yield (6). The seeds of nearly all species of 
Vigna have antioxidant properties and are used to treat different diseases like rheumatism, liver diseases, diabetes, coughs, cancer, fevers, microbial infections, kidney disorders, paralysis, hormonal disorders and for weight reduction (7-8). Therefore further research is required to find out pharmacognostic importance of individual components of these species.

\section{Medicinal importance of a few Vigna species}

\section{V. mungo (Blackgram)}

Blackgram/urdbean (V. mungo (L.) Hepper), a selfpollinating diploid $(2 n=2 x=22)$ short duration legume crop (90-120 days) originated in India which is the largest consumer and producer (9-10). In India, it is widely grown in the rainy season and gives around $20 \%$ to the overall world pulse production (11-12). It is important in cropping systems as it adds to soil fertility due to nitrogen fixing capacity of symbiotic bacteria in nodules. It constitutes an integral part of human diet due to high nutritive value as mature dry seeds that possess proteins, vitamins, amino acids and lipids (13-14). Immature seeds or green pods are used as food for animals in the form of hay and straw. Seeds are highly nutritive (calorific value-350cal/100g) containing about $24-26 \%$ protein, $60 \%$ carbohydrates, $1.3 \%$ fats, phosphorus (345mg/100g), potassium, iron $(8.7 \mathrm{mg} / 100 \mathrm{~g})$, calcium (185mg/100g), amino acids (arginine, phenylalanine, leucine, lysine, valine and isoleucine etc.), niacin $(2 \mathrm{mg} / 100 \mathrm{~g})$ and vitamins B1 $(0.42 \mathrm{mg} / 100 \mathrm{~g}), \mathrm{A}$, and B2 $(0.37 \mathrm{mg} / 100 \mathrm{~g})$ (9). Since ancient time it has been in use as medicinal as well as cosmetic material (15-16). It is used to treat nervous disorder, sexual dysfunction, diabetes, hair disorders, rheumatic afflictions and digestive system disorders etc.

\section{V. radiata (Green gram)}

This is a widely grown legume of Vigna species in India. It is used as food and medicine due to higher ratio of vitamins, calcium, irons and phosphorus in compare to other legumes. Contents of green gram such as amino acids, proteins, polyphenols and oligosaccharides possess antioxidant, antitumor, anti-inflammatory and antimicrobial activities (17-20); flavonoids and phytosterols possess certain degree of anti-bacterial and antiviral effects; coumarins, alkaloid, phytosterols and saponins enhance the immune system and increase the amount of phagocytic cell; protein and phospholipid enhance appetite and excite nerves; polysaccharides avoid the chances of coronary heart disease and angina cordis (7); trypsin inhibitors, hem agglutinin, tannins, and phytic acid enhance the digestion and remove the toxins (21); a-tocopherol (antioxidant) reduces the risk of certain types of cancer and cardiovascular diseases (22-23); $\quad \gamma$-tocopherol reduces LDL oxidation, platelet aggregation, and delaying intra- arterial thrombus formation (24-25). Studies reported that methanolic extract contains anti inflammatory activity that may inhibits the prostaglandin synthesis (26). Bark and fruits are more important in comparison to other parts of plant.

\section{V. unguiculata (Cowpea)}

Since Neolithic times Cowpea is used as food source (27). It is widely grown legume crop in developing countries of Africa, Northern and North-eastern regions of Brazil, Latin America, and Asia due to their highly nutritive value at low cost (28-31). Whole plant parts are consumed as a food or forage legume (32-33) like tender shoot tips and leaves are used as vegetable in seedling stage; immature pods and seeds are eaten in the fruiting stage; mature dry seeds are used to prepare cowpea cake, or deep fried into bean balls, or the seeds could be boiled, mixed with sauce or stew and consumed directly. Cowpea is used by low income population who suffer from iron and zinc deficiencies (malnutrition and micronutrient deficiencies) in Brazil (34). Medicinal value of cowpea is also observed (35) who reported cowpea is an important legume crop to manage, prevent and cure the degenerative diseases linked with free radical damage (35).

\section{V. subterranea (Bambara groundnut)}

This legume plant from Vigna genus is under researched and in Africa, the second most important indigenous food legume (36). It is believed that bambara groundnut is a drought tolerant crop as it is able to grow in poor soils and harsh climatic conditions (37-38). Development of pods are underground and seeds are used as foodstuff. Average production of bambara groundnut is about $300-800 \mathrm{~kg} /$ ha (39). It may reach the level of $3000 \mathrm{~kg} / \mathrm{ha}$ and $100 \mathrm{~kg} / \mathrm{ha}$ depending on various growth conditions (39-40).

\section{Phytochemical constituents and pharmaco- logical properties reported in Vigna}

Formulation of a new drug has been done by using black gram flour contains mucilage which has the ability to sustain the release of freely soluble drug (41). It is reported that blackgram contains hypoglycaemic action. Its extract used in rheumatism and roots contain narcotic property (42). Green gram is highly nutritive and possesses rich amount of iron and phosphorus (43). Absence of canavanine (non protein amino acid) in seeds and proanthocyanidin (polyphenol) in leaves were reported in biochemical study of eleven species of Vigna (44). Bioactive compounds like $\beta$-sitosterol, stigmasterol, soyasapogenol C, 1,4-butanediamine, 3-(carboxy methyl amino) propanoic acid, $1 \mathrm{H}$ Imidazole, spermidine, spermine, amino acids and peptides are isolated from $V$. radiata seeds (45). Induction of phenyl propanoid pathway (PPP) has been reported through the pentose phosphate and 
shikimic acid pathways, by natural elicitors (fish protein hydrolysates (FPH), lactoferrin (LF) and oregano extract (OE)) in sprouts of $V$. mungo (46). Isolation of phosphorylase and Q- enzyme (starch metabolizing enzymes) have been done from aqueous extracts of $V$. radiata seeds (47). Antioxidative properties and total phenolic contents were studied via the extraction with $70 \%$ acetone in two varieties of cowpea (48). The pulses are also reported to possess cholesterol lowering effect and serum phospholipid lowering effect (49). Several anthocyanins including delphinidin-3glucoside is reported from Vigna (50). Phosphoenolpyruvate phosphatase (PEP) has also been characterised from germinating green gram (51). In germinating blackgram interconversion of (-)-quinic acid and 3-dehydro quinic acid is reported (52). BGL-I-1 (94 kDa) and BGL-I-2 (89 $\mathrm{kDa}$ ) are obtained by partial purification of BGL-I (galactose-specific lectins) in blackgram (53). Antioxidant mechanism has been studied in green gram seeds and antioxidant activity reported using DPPH method and ferric reducing activity in cowpea (54). Phytoestrogens are reported in the extract of seven legumes by using an estrogendependent MCF-7 breast cancer cell proliferation assay (55). All plant parts (seeds, leaves, stems and roots) possess trypsin inhibitor (56). Comparative phytochemical studies on legumes have been done by using the technique GC-MS and LC-MS (57). Evaluation of any immunostimulatory activities in an animal model via the extract of green gram seeds has been done (58).

\section{Conclusion}

Nowadays several traditional medicines are in international market but the genus Vigna with around 150 species, have received little attention. Therefore it is require to find out the medicinal importance of individual parts of these plants, to manage, prevent and cure diseases. In this review it is concluded that many species of Vigna possess antioxidant activity and able to manage and cure different diseases linked with free radical generation. To fulfil the demand of efficient, safe and cheap medications, there is a need to understand the taxanomical characters of various medicinal plants, climatic conditions, various folklore usages, phytochemical, pharmacological, antimicrobial values and it is possible by the collaborative work of botanist, phytochemist and pharmacist.

\section{Competing interest}

The author declares no conflict of interest.

\section{Acknowledgement}

Author would like to acknowledge Dr. Dipjyoti Chakraborty (Head of Department), Department of
Bioscience and Biotechnology, Banasthali Vidyapith, Rajasthan for all the required guidance related to this review article. The work is funded through a UGC, Govt. Of India, Major Research Project to Dr. Dipjyoti Chakraborty. Author thankfully acknowledge UGC for fellowship.

\section{References}

1. Sheth BP, Punia S, Dheer M, Rakhashiya PM, Patel PP, Thaker VS. Phylogenetic implications and secondary structure analyses of Vigna mungo (L.) Hepper genotypes based on nrDNA ITS2 sequences. Computational Biology and Chemistry. 2019;78:389-97. https://doi.org/10.1016/j.compbiolchem.2018.12.018

2. Varshney RK, Close TJ, Singh NK, Hoisington DA, Cook DR. Orphan legume crops enter the genomics era. Current Opinion in Plant Biology. 2009;12(2):202-10. https://doi.org/10.1016/j.pbi.2008.12.004

3. Gupta SK, Gopalakrishna T. Advances in genome mapping in orphan grain legumes of genus Vigna. Indian Journal of Genetics. 2013;73(1):1-13. DOI : 10.5958/j.00195200.73.1.001

4. Harouna DV, Venkataramana PB, Matemu AO, Ndakidemi PA. Wild Vigna legumes: farmers perceptions, preferences, and prospective uses for human exploitation. Agronomy.2019;9(6):284. https://doi.org/10.3390/agronomy9060284

5. Pandey S, Verma A, Chakraborty D. Potential use of rhizobacteria as biofertilizer and its role in increasing tolerance to drought stress. In: Pati BR, Mandal SM, editors. Recent Trends in Biofertilizers: 2015. p. 116-40.

6. Pandey S, Chakraborty D. Salicylic acid and drought stress response: biochemical to molecular crosstalk. In: Tripathi BN, Muller M, editors. Stress responses in plants: mechanisms of toxicity and tolerance. Springer Cham Heidelberg New York Dordrecht London: 2015. p 247-66.

7. Battu G, Ch KVL, Male SNA, Priya TH, Malleswari VN, Reeshma SK. A phytopharmacological review on Vigna species. Pharmanest. 2011;2(1):61-7. ISSN: 0976 - 3090 (Print) 2231 - 0541 (Online).

8. Pandey S, Chakraborty D. Agro - morphological response of three Vigna mungo varieties (T9, RBU38 and VM4) to soil water deficit. International Journal of Scientific Research in Agricultural Sciences. 2016;3(2):36-41. http:// dx.doi.org/10.12983/ijsras-2016-p0036-0041

9. Hussain N, Mehdi M, Kant RH. Response of nitrogen and phosphorus on growth and yield attributes of black gram (Vigna mungo). Journal of Agricultural Sciences. 2011;2(2):334-36.

10. Pandey S, Ror S, Chakraborty D. Analysis of biochemical responses in Vigna mungo varieties subjected to drought stress and possible amelioration. International Journal of Scientific Research in Agricultural Sciences. 2014;1(1):6-15. $\quad$ http://dx.doi.org/10.12983/ijsras-2014p0006-0015

11. Saravanakumar D, Harish S, Loganathan M, Vivekananthan $R$, Rajendran L, Raguchander $T$, Samiyappan R. Rhizobacterial bioformulation for the effective management of Macrophomina root rot in mungbean. Archives of Phytopathology and Plant Protection. 2007;40(5):323-37. https://doi.org/10.1080/03235400600587326

12. Pandey S, Chakraborty D. Biochemical response of three Vigna mungo varieties (T9, RBU38 and VM4) under drought stress. Plant Science Today. 2015;2(2):60-4. https://doi.org/10.14719/pst.2015.2.2.99 
13. Agugo UA, Onimawo IA. Heat treatment on the nutritional value of mung bean. Electronic Journal of Environmental, Agricultural \& Food Chemistry. 2009;8(10):924-30.

14. Suneja Y, Kaur S, Gupta AK, Kaur N. Levels of nutritional constituents and anti nutritional factors in black gram (Vigna mungo L.). Food Research International 2011;44(2):621-28.

https://doi.org/10.1016/j.foodres.2010.12.020

15. Jo BK, Ahn GW, Jeong JH, Hwang YI. Clinical studies on the anti-irritation effects of mung bean (Phaseolus aureus) extract in cosmetics. SOFW-J. 2006;132(1/2):8-10.

16. Sharma P, Mishra NK. Ethno-medicinal uses and agrobiodiversity of barmana region in Bilaspur district of Himachal Pradesh, Northwestern Himalaya. Ethanobotanical Leaflets. 2009;13:709-21. https://opensiuc.lib.siu.edu/ebl/vol2009/iss6/5

17. Randhir R, Lin YT, Shetty K. Stimulation of phenolics, antioxidant and antimicrobial activities in dark germinated mung bean sprouts in response to peptide and phytochemical elicitors. Process Biochemistry. 2004;39(5):637-46. https://doi.org/10.1016/S0032-9592(03)00197-3

18. Vanamala J, Reddivari L, Yoo KS, Pike LM, Patil BS. Variation in the content of bioactive flavonoids in different brands of orange and grape fruit juices. Journal of Food Composition and Analysis. 2006;19(2-3):157-66. https://doi.org/10.1016/i.jfca.2005.06.002

19. Anjum NA, Umar S, Iqbal M, Khan NA. Cadmium causes oxidative stress in mung bean by affecting the antioxidant enzyme system and ascorbate glutathione cycle metabolism. Russian Journal of Plant Physiology. 2011;58(1):92-9.

https://doi.org/10.1134/S1021443710061019

20. Kanatt SR, Arjun K, Sharma A. Antioxidant and antimicrobial activity of legume hulls. Food Research International. https://doi.org/10.1016/i.foodres.2011.08.022

21. Kudre TG, Benjakul S, Kishimura H. Comparative study on chemical compositions and properties of protein isolates from mung bean, black bean and bambara groundnut. Journal of the Science of Food and Agriculture. https://doi.org/10.1002/jsfa.6052

22. Zia-Ul-Haq M, Ahmad M, Iqbal S. Characteristics of oil from seeds of 4 mungbean (Vigna radiata (L.) Wilczek) cultivars grown in Pakistan. Journal of the American Oil Chemists' https://doi.org/10.1007/s11746-008-1269-Z

23. Zia-Ul-Haq M, Ahmad S, Iqbal S, Luthria DL, Amarowicz R. Antioxidant potential of lentil cultivars commonly consumed in Pakistan. Oxidation Communications. 2011;34:819-31.

24. Awika JM, Rooney LW, Wu X, Prior RL, Zevallos LC. Screening methods to measure antioxidant activity of sorghum (Sorghum bicolor) and sorghum products. Journal of Agricultural and Food Chemistry. 2003;51(23):6657-662. https://doi.org/10.1021/jf034790i

25. Amarowicz R, Troszynska A, Barylko-Pikielna N, Shahidi F. Polyphenolics extracts from legume seeds correlation between total antioxidant activity, total phenolics content, tannins content and astringency. Journal of Food Lipids. 2004;11(4):278-86. https://doi.org/10.1111/j.1745-4522.2004.01143.x

26. Nishanthi M, Aanandhi MV, Raj KA, Vijayakumar B. Evaluation of in-vitro anti-inflammatory activity of methanolic leaf extract of Vigna radiata (L.) Wileze. International Journal of Pharmacological Screening Methods. 2012;2(2):88-91.
27. Summerfield RJ, Huxley PA, Steelle W. Cowpea (Vigna unguiculata (L.) Walp). Field Crop Abstracts. 1974;27:301-12.

28. Nielsen SS, Ohler TA, Mitchell CA. Cowpea leaves for human consumption: production, utilization, and nutrient composition. In: Singh BB, Mohan Raj DRR, Dashiell KE, Jackai, LEN, editors. Advances in cowpea research. Co-publication of International Institute of Tropical Agriculture (IITA) and Japan International Centre for Agricultural Sciences (JIRCAS), IITA, Ibadan. Nigeria: 1997. p. 326-32.

29. Phillips RD, Mcwatters KH, Chinannan MS, Hung YC, Beuchat LR, Sefa-Dedeh S, et al. Utilization of cowpeas for human food. Field Crops Research. 2003;82(2-3):193213. https://doi.org/10.1016/S0378-4290(03)00038-8

30. Keller GD, Mndiga H, Maass BL. Diversity and genetic erosion of traditional vegetables in Tanzania from the farmer's point of view. Plant Genetic Resources. 2006;3(3):400-13. https://doi.org/10.1079/PGR200594

31. Tefera TA. Towards improved vegetable use and conservation of cowpea (Vigna unguiculata) and lablab (Lablab purpureus): Agronomic and participatory evaluation in northeastern Tanzania and genetic diversity study. PhD (thesis). Cuvillier Verlag, Gottingen, Germany. 2006. p. 214.

32. Brink GE, Fairbrother TE. Cool- and warm season forage legume potential for the southeastern USA. Tropical Grasslands. 1988;22(3):116-25.

33. Lenne JM, Fernandez-Rivera S, Blummel M. Approaches to improve the utilization of food-feed crops - synthesis. Field Crops Research. 2003;84(1-2):213-22. https://doi.org/10.1016/S0378-4290(03)00152-7

34. Pereira EJ, Carvalho LMJ, Dellamora-Ortiz GM, Cardoso FSN, Carvalho JLV, Viana DS, Freitas SC, Rocha MM. Effects of cooking methods on the iron and zinc contents in cowpea (Vigna unguiculata) to combat nutritional deficiencies in Brazil. Food and Nutrition Research. 2014;58(1):20694. https://doi.org/10.3402/fnr.v58.20694

35. Zia-Ul-Haq $M$, Ahmad S, Amarowicz R, De Feo V. Antioxidant activity of the extracts of some cowpea (Vigna unguiculata (L) Walp.) cultivars commonly consumed in Pakistan. Molecules. 2013;18(2):2005-2017. https://doi.org/10.3390/molecules18022005

36. Mohale KC, Belane AK, Dakora FD. Symbiotic N nutrition, $\mathrm{C}$ assimilation, and plant water use efficiency in Bambara groundnut (Vigna subterranea (L.) Verdc) grown in farmers' fields in South Africa, measured using $15 \mathrm{~N}$ and $13 \mathrm{C}$ natural abundance. Biology and Fertility of Soils. 2014;50(2):307-19. https://doi.org/10.1007/s00374$\underline{013-0841-3}$

37. Doku EV. Growth habit and pod production in Bambara groundnuts (Voandzeia subterranea). Ghana Journal of Agricultural Sciences. 1970;2:91-5.

38. Tweneboah CK. Modern agriculture in the tropics, Food crops. Cowood Publishers; 2000.

39. Brink M, Ramolemana GM, Sibuga KP. Vigna subterranea (L.) Verdc', PROTA (Plant Resources of Tropical Africa), Wageningen, Netherlands. 2006

40. Baudoin JP, Mergeai G. Grain legumes, In: Crop production in Tropical Africa, 2001. p. 313-17.

41. Sravani B, Deveswaran R, Bharath S, Basavaraj BV, Madhavan V. Studies on Vigna mungo mucilage as a pharmaceutical excipient. Journal of Chemical and Pharmaceutical Research. 2011;3(2):118-25. http://jocpr.com/vol3-iss2-2011/JCPR-

42. Kirtikar KR, Basu BD. Indian Medicinal Plants. 2nd ed., Vol. 3, International Book Distributors; Dehra Dun, India: 2005. ISBN: 10-8170892791. 
43. Kumar S, Yadav SS, Tripura P, Jatav HS. Use of phosphorus for maximization of mungbean (Vigna radiata (L.) Wilszeck) productivity under semi-arid condition of Rajasthan, India. International Journal of Current Microbiology and Applied Sciences. 2017;6(2):612-17.

http://dx.doi.org/10.20546/ijcmas.2017.602.069

44. Onyilagha JC, Islam S, Ntamatungiro S. Comparative phytochemistry of eleven species of Vigna (Fabaceae). Biochemical Systematics and Ecology. 2009;37(1):16-19. https://doi.org/10.1016/j.bse.2008.11.013

45. Kasai T, Shiroshita Y, Sakamura S. Gutamyl peptides of Vigna radiata seeds. Phytochemistry. 1986;25(3):679-82. https://doi.org/10.1016/0031-9422(86)88023-2

46. Randhir R, Lin YT, Shetty K. Stimulation of phenolics, antioxidant and antimicrobial activities in dark germinated mung bean sprouts in response to peptide and phytochemical elicitors. Process Biochemistry. 2004;39(5):637-46.

https://doi.org/10.1016/S0032-9592(03)00197-3

47. Quemener B, Brillouet JM, Arendt M, Tome D, Diolez C. Possible misidentification of pipecolic acid in HPLC analysis of legume phaseoleae seed oligosaccharides. Journal of Agricultural and Food Chemistry. 1986;34(2):282-84. https://doi.org/10.1021/jf00068a034

48. Siddhuraju P, Becker K. The antioxidant and free radical scavenging activities of processed cowpea (Vigna unguiculata (L.) Walp.) seed extracts. Food Chemistry. 2007;101(1):10-19.

https://doi.org/10.1016/j.foodchem.2006.01.004

49. Baveja SK, Rangarao KV, Arora J. Examination of natural gums and mucilages as sustaining materials in tablet dosage forms -Part II. Indian Journal of Pharmaceutical Sciences. 1989;51:115-18.

50. Pale E, Nacro M, Vanhaelen M, Vanhaelen-Fastré R. Anthocyanins from bambara groundnut (Vigna subterranea). Journal of Agricultural and Food Chemistry. https://doi.org/10.1021/jf960897c

51. Podesta FE, Plaxton WC. Association of phoshoenol pyruvate phosphatase activity with the cytosolic pyruvate kinase of germinating mung beans. Plant Physiology.

https://doi.org/10.1104/pp.97.4.1329

52. Takeuchi W, Takahashi H, Kojima M. Purification and characterization of the main isozyme of polyphenol oxidase in mungbean (Vigna mungo) seedling. Bioscience, Biotechnology, and Biochemistry. 1992:56(7):1134-35. https://doi.org/10.1271/bbb.56.1134

53. Suseelan KN, Bhatia CR, Mitra R. Purification and characterization of two major lectins from Vigna mungo (Blackgram). Journal of Biosciences. 1997;22(4):439-55. https://doi.org/10.1007/BF02703190

54. Siddhuraju P. The antioxidant activity and free radical scavenging capacity of phenolics of raw and dry heated moth bean (Vigna aconitifolia) Marechal seed extracts. Food Chemistry. 2006;99(1):149-57. https://doi.org/10.1016/j.foodchem.2005.07.029

55. Boue SM, Wiese TE, et al. Evaluation of the estrogenic effects of legume extracts containing phytoestrogens. Journal of Agricultural and Food Chemistry. 2003;51(8):2193-99. https://doi.org/10.1021/jf021114s

56. Pullaiah T. Encyclopedia of world medicinal plants. Regency publications: 2006;1:2050-2051.

57. Kite GC, Veitch NC, Grayer RJ, Simmonds MSJ. The use of hyphenated techniques in comparative phytochemical studies of legumes. Biochemical Systematics and
Ecology.

2003;31(8):813-43. https://doi.org/10.1016/S0305-1978(03)00086-3

58. Solanki YB, Jain SM. Immunostimolatory activities of Vigna mungo L. extract in male sprague-dawley rats. Journal of Immunotoxicology. 2010;7(3):213-18. https://doi.org/10.3109/15476911003792278

59. Medicinal plants in papua new guinea. World Health Organisation: 2009. ISBN: 978-92-9061-249-0.

60. Chatterjee A, Pakrashi SC. The treatise on Indian medicinal plants, publications and information directorate, New Delhi 2:1994;188-90.

61. Kirtikar KR, Basu BD, An ICS. Indian medicinal plants, Dehra Dun: Lalit Mohan Basu M.B. 1998;1:340-43.

62. Huijie NC, Yuxhen NL, Wanberger K. The impact of mung bean research in China. Shanhua AVDRC Publication No. 03-350. Working paper. 2003. 14: p. 26.

63. Leung Albert A. Better health with (mostly) Chinese herbs and food: $2007 . \quad$ Mungbean. http://www.earthpower.com. 7/1/2009.

64. Kumar VL, Singhal A. Germinating seeds of the mung bean, Vigna radiata (Fabaceae), as a model for the preliminary evaluation of cytotoxic effects of drugs. Biocell. 2009;33(1):19-24. ISSN 0327 - 9545

65. Kruawan K, Tongyonk L, Kangsadalampai K. Antimutagenic and comutagenic activities of some legume seeds and their seed coats. Journal of Medicinal Plant Research. 2012;6(22):3845-851. DOI: 10.5897/JMPR12.243

66. Shaheen S, Harun N, Khan F, Hussain RA, Ramzan S, Rani S, Khalid Z, Ahmad M, Zafar M. Comparative nutritional analysis between Vigna radiata and Vigna mungo of Pakistan. African Journal of Biotechnology. 2012;11(25):6694-702. http://dx.doi.org/10.5897/AJB11.3496

67. Tang D, Dong $\mathrm{Y}$, Ren $\mathrm{H}$, Li L, He C. A review of phytochemistry, metabolite changes, and medicinal uses of the common food mung bean and its sprouts (Vigna radiata). Chemistry Central Journal. 2014;8:4 https://doi.org/10.1186/1752-153X-8-4

68. Cozzolino SMF. Biodisponibilidade de Nutrientes. Barueri, Brazil: Editora Manole Ltda; 2005. p. 76-87.

69. Indira $\mathrm{M}$, Kurup PA. Blackgram (Vigna mungo)- a hypolipimic pulse. Natural Product Radiance. 2003;2(5):240-42. http://hdl.handle.net/123456789/12287

70. Gary Null A. A complete guide to prevention, treatment and healthy living 2nd Edition: Get healthy now. 2006. p. 126-33.

71. Lin MJY, Humbert ES, Sosulski FW. Certain functional properties of Sunflower seed proteins. Journal of Food Science. 2006;39(2):368-70 https://doi.org/10.1111/j.1365-2621.1974.tb02896.x

72. Yang JK, Yuan TY, Zhang WT, Zhou JC, Li YG. Polyphasic characterization of mung bean (Vigna radiata L.,) from different geographical regions of China. Soil Biology and Biochemistry. 2008;40(7):1681-88. https://doi.org/10.1016/ j.soilbio.2008.02.002

73. Usman MRM, Barhate SD. Anti-inflammatory, analgesic and ulcerogenic activity of Vigna mungo Linn. leaves. International Journal of Phytopharmacology. 2011;1(2):55-60

74. Anbuselvi S, Rebecca LJ. GC-MS study of phytochemicals in black gram using two different organic manures. BioMedRx. 2013;1(1):74-77.

75. Usman MRM, Barhate SD. Estimation of phytoconstituents and evaluation of anti-inflammatory activity of Vigna mungo Linn. Seeds. International 
Journal of Research in Pharmaceutical Sciences. 2012;3(1):106-12. https://pharmascope.org/index.php/ijrps/ article/view/1004

76. Sherlina, FP, Gayathri V, Radha SR. Preliminary phytochemical analysis of black gram, Vigna mungo L. International Journal of Development Research. 2013;3(11):147-49.

77. Yao Y, Cheng X, Wang L, Wang S, Ren G. A determination of potential a-glucosidase inhibitors from azuki beans (Vigna angularis). International Journal of Molecular Sciences. 2011;12(10):6445-451. https://doi.org/10.3390/ijms12106445

78. Ramesh CK, Rehman A, Prabhakar BT, Avin BRV, Rao SJR. Antioxidant potentials in sprouts vs. seeds of Vigna radiata and Macrotyloma uniflorum. Journal of Applied Pharmaceutical Science. 2011;01(07):99-103.

79. Priya AJP, SudhaLakshmi GY, Banu F, Gopalakrishnan S, Dhanalakshmi P, Sagadevan E, Manimaran A Arumugam P. Phytochemical screening and antibacterial activity of Vigna radiata L. against bacterial pathogens involved in food spoilage and food borne diseases. Journal of Academia and Industrial Research. 2012;1(6):355-59.

80. Mbagwu FN, Okafor VU, Ekeanyanwu J. Phytochemical screening on four edible legumes (Vigna subterranea, Glycine max, Arachis hypogea and Vigna unguiculata) found in eastern Nigeria. African Journal of Plant Science. http://www.academicjournals.org/ajps 2011;5(6):370-72.

81. Simeone EI, Tufon EN, Victor ON, Noel NN. Antisickling potential of the ethanol seed extracts of Vigna unguiculata and Vigna subterranea. International
Journal of Biochemistry and Biotechnology. 2012;1(9):226-29. http://internationalscholarsjournals.org

82. Cheekuramelli NS, Ramani ND, Janarthan M, Durraive S. Protective effect of Vigna aconitifolia methanolic seed extract against smokeless tobacco (gutka) chewing and on chemically induced hepatotoxicity and nephrotoxicity in rats. Journal of Pharmacy and Pharmaceutical Sciences. 2014;6(4):88-95.

83. Maisale AB, Patil MB, Jalalpure SS, Patil AM, Attimarad SL. Phytochemical properties and anthelmintic activity of Vigna unguiculata Linn. Journal of Pharmaceutical and Scientific Innovation. 2012;1(2):51-52.

84. Sandeep D. Evaluation of antibacterial activity of seed extracts of Vigna unguiculata. International Journal of Pharmacy and Pharmaceutical Sciences. 2014;6(1):75-77.

85. Tazin TQ, Rumi JF, Rahman S, Al-Nahain A, Jahan R, Rahmatullah M. Oral glucose tolerance and antinociceptive activity evaluation of methanolic extract of Vigna unguiculata ssp. unguiculata beans. World Journal of Pharmacy and Pharmaceutical Sciences. 2014;3(8):28-37

86. Li L, Gong X, Ren H, Wang X, He Y, Dong Y. Increased polyphenols and antioxidant activity of rice bean (Vigna umbellata L.) sprouts induced by Methyl Jasmonate: the promotion effect of Methyl Jasmonate on rice bean sprouts. Food Science and Technology Campinas. 2019;39:98-104. http://dx.doi.org/10.1590/fst.36717

87. Leu YL, Hwang TL, Kuo PC, Liou KP, Huang BS, Chen GF. 2012. Constituents from Vigna vexillata and their antiInflammatory activity. International Journal of Molecular $\quad$ Sciences. 2012;13(8):9754-768. https://doi.org/10.3390/ijms13089754 